\title{
Retinoblastoma Pathologic TNM Finding v8
}

National Cancer Institute

\section{Source}

National Cancer Institute. Retinoblastoma Pathologic TNM Finding v8. NCI Thesaurus. Code C140704.

A pathologic finding about one or more characteristics of retinoblastoma, following the rules of the TNM AJCC v8 classification system. 